\title{
EVALUASI KINERJA KOMITE SEKOLAH DAN PENINGKATAN MUTU PADA SEKOLAH MENENGAH ATAS DI KABUPATEN LAMPUNG UTARA
}

\author{
${ }^{1}$ Eny Munisah \\ enymuni0@gmail.com
}

\section{Universitas Muhammadiyah Kotabumi}

\begin{abstract}
This research is aimed at describing school committee's performance for education quality improvement at both public and private senior high schools in Lampung Utara Regency. The research applied objective-oriented approach evaluation. The research subjects were purposively determined, i.e. public senior high schools and two private senior high schools in Lampung Utara Regency. Each of the schools was made up of one principal, five non-committee teachers, and five non-committee parents of students. The variables were school committee's performance and school quality. Closed questionnaire was used to collect the data. The data were then analyzed using quantitative percentage and descriptive techniques.
\end{abstract}

Key Word: Evaluation, Committee's, Education Quality Improvement

\begin{abstract}
Abstrak: Penelitian ini bertujuan untuk mendeskripsikan kinerja komite sekolah dalam peningkatan mutu pendidikan di SMA Negeri dan Swasta di Kabupaten Lampung Utara. Penyelidikan ini memakai strategi penilaian yang berorientasi pada tujuan. Subjek penyelidikan ditentukan secara purposive yaitu SMA negeri 02 dan SMA swasta di Kabupaten Lampung Utara. Masing-masing sekolah terdiri dari satu kepala sekolah, lima guru non-komite, dan lima wali murid non-komite. Variabelnya adalah kinerja komite sekolah dan kualitas sekolah. Kuesioner tertutup digunakan untuk mengumpulkan data. Data tersebut lalu dianalisis dengan memakai teknik persentase kuantitatif dan deskriptif. Kata Kunci,
\end{abstract}

Kata Kunci: Evaluasi, Kinerja Komite Sekolah, Peningkatan Mutu

\section{A. PENDAhuluan}

Pendidikan merupakan kewajiban peran serta antara wali murid, masyarakat dan pemerintah. (Depdiknas, 2013). Kenyataan di lapangan kewajiban masing-masing belum dilaksanakan secara optimal. Lebih-lebih peran serta masysrakat kurang difungsikan untuk berpartisipasi di sekolah. Karena tujuan pembangunan pendidikan untuk mewujudkan bagian yang tak terpisahkan dalam usaha pembangunan manusia. Kiat pembangunan diaspek pendidikan, yang paling utama ditujukan untuk menciptakan ketentraman manusia itu sendiri. Kemudian pendidikan mencorakkan kewajiban setiap warga negara didalamnya tercantum kegunaan bahwa pembagian fasilitas pendidikan kepada individu, masyarakat, dan warga negara adalah kewajiban bersama-sama antara pemerintah, masyarakat, dan keluarga.

Dalam UU No. 20 tahun 2003 tentang Sistem Pendidikan Nasional antara lain salah satu sasarannya yaitu menguatkan fungsi masyarakat dalam pengelolaan pendidikan berlandaskan azas otonomi daerah dalam kerangka Negara Kesatuan Republik Indonesia. (Redaksi Sinar Grafika, 2003). Kelak 
masyarakat ikut serta dalam kenaikan kualitas bantuan pendidikan adalah perencanaan, pengawasan, dan evaluasi program pendidikan menggunakan badan pendidikan dan komite sekolah/madrasah. (Wibisono, 2011). Pembaharuan pendidikan dasar dan menengah adalah mengaktualkan pengelolaan pendidikan yang berbasis sekolah/masyarakat dengan menghadirkan badan pendidikan di tingkat Kabupaten /kota serta mengaktualkan atau mendirikan komite sekolah di tingkat sekolah. (Suryadi, 2013).

Komite sekolah dibentuk sebagai bagian dari implementasi manajemen berbasis sekolah (MBS), dan mempunyai kewajiban untuk mengatur dirinya sendiri. (Mulyasa, 2013) Implementasi sekolah ini dijalankan dengan prinsip keikutsertaan, keterbukaan dan reponssibilitas, artinya dalam implementasi sekolah dewan pendidikan khususnya kepala sekolah berkolaborasi dengan masysrakat sekolah. (Sukmadinata, 2014). Untuk itu dibutuhkan tempat yang dapat digunakan oleh masyarakat sekolah untuk menjalankan tanggung jawab tersebut. Tempat tersebut adalah komite sekolah.

\section{B. TUJUAN PENELITIAN}

Tujuan penelitian ini secara universal dapat menggambarkan. (Depdiknas, 2014) ,kinerja komite sekolah dalam rangka peningkatan kualitas pendidikan di SMA negeri dan swasta di Kabupaten Lampung Utara. Secara spesifik bertujuan sebagai berikut:

a. Mendapatkan informasi tentang kinerja momite sekolah SMA negeri dan swasta di
Kabupaten Lampung Utara dalam menjalankan tugas dan fungsinya baik selaku penyumbang pendapat/advisory agency, selaku simpatisan kegiatan layanan pendidikan/supporting agency, pengontrol kegiatan layanan pendidikan/controlling agency dan selaku penyambung/mediator.

b. Memperoleh peningkatan kualitas sekolah di SMA negeri dan swasta Kabupaten Lampung Utara.

\section{METODE PENELITIAN}

Penelitian ini menerapkan strategi penilaian yang mengarah pada tujuan (objectives oriented approaches). (Sukmadinata, 2013). Subyek penelitian ditetapkan secara purposive yaitu SMA Negeri 2 dan SMA swasta SMA Hang Tuah Kabupaten Lampung Utara, tahun 2021. Setiap sekolah terdiri dari 1 orang kepala sekolah, 5 orang guru nonkomite sekolah, 5 orang tua nonkomite sekolah. Variabel dalam penelitian ini adalah kinerja komite sekolah dan mutu sekolah. Untuk mengumpulkan data digunakan angket tertutup. Data dianalisis dengan teknik kuantitatif persentase dan diskriptif.

\section{HASIL PENELITIAN}

\section{a. Kinerja Komite Sekolah SMA Negeri 02}

1) Dimensi Pemberi Pertimbangan/Advisory Agensy

Berdasarkan analisis, dapat diketahui bahwa kinerja komite SMA negeri 02 dalam dimensi pemberi pertimbangan/ 
advisory agency menurut kepala sekolah masih kurang berhasil (66\%). Aspek yang belum berhasil yaitu dalam hal menyampaikan pandangan perihal tenaga kependidikan yang dapat diberikan di sekolah dan memberikan pandangan perihal fasilitas yang dapat diberikan di sekolah. Aspek yang belum berhasil yaitu dalam hal membantu menyusun masukan untuk penyusunan RAPBS. Menurut guru nonkomite kinerja komite dalam menyampaikan pandangan sudah berhasil (83\%). Aspek yang belum begitu berhasil yaitu dalam hal menyampaikan pandangan saat menyelenggarakan rapat RAPBS dan dalam menyampaikan pandangan terkait fasilitas yang dapat disampaikan di sekolah. Menurut orangtua nonkomite sudah sangat berhasil (97\%). Aspek yang belum begitu berhasil yaitu dalam hal menyampaikan pandangan perihal fasilitas yang dapat diberikan di sekolah.

2) Dimensi Penunjang Kegiatan Layanan Pendidikan/SupportingAgency

Berdasarkan analisis data, dapat diketahui bahwa kinerja komite SMA negeri 02 dalam dimensi pendukung kegiatan layanan pendidikan/supportingagency menurut menurut kepala sekolah sudah sangat berhasil (100\%). Aspek yang berlum berhasil yaitu dalam hal memantau proses perancangan pendidikan di sekolah. Menurut guru nonkomite kinerja komite dalam dimensi pendukung kegiatan layanan pendidikan sudah berhasil $(90,62)$. Aspek yang belum begitu berhasil yaitu dalam melakukan penjagaan terhadap mutu perancangan sekolah, melakukan penjagaan terhadap penjadwalan agenda sekolah, dan mengawasi hasil ujian akhir. Menurut orangtua nonkomite, peran komite dalam dimensi pendukung kegiatan layanan pendidikan sudah sangat berhasil (90,48\%). Aspek yang belum berhasil antara lain dalam hal melakukan penjagaan terhadap mutu perancangan sekolah dan mengawasi angka bertahan sekolah.

3) Dimensi Pengontrol Kegiatan Layanan Pendidikan, Controling Agency

Berdasarkan analisis data, dapat diketahui bahwa kinerja komite SMA negeri 02 dalam dimensi pengontrol kegiatan layanan pendidikan/controlingagencymenurut kepala sekolah sudah sangat berhasil (100\%). Aspek yang belum berhasil yaitu dalam hal memonitor proses perancangan pendidikan di sekolah dan penjadwalan program sekolah. Menurut guru nonkomite juga sudah berhasil (72,72\%). Aspek yang belum berhasil yaitu dalam hal memeriksa proses perancangan pendidikan di sekolah dan penjadwalan agenda sekolah. Menurut orangtua nonkomite sangat berhasil (90\%). Aspek yang 
belum berhasil yaitu dalam hal memeriksa proses perancangan pendidikan di sekolah dan memonitor alokasi anggaran untuk implementasi program sekolah.

4) Dimensi Penghubung/MedutorAgency Berdasarkan analisis data, dapat diketahui bahwa kinerja komite SMA negeri 02 dalam dimensi penghubung/meduitor agency menurut kepala sekolah kurang berhasil (50\%). Aspek yang belum berhasil yaitu dalam hal melaksanakan penyelidikan tentang kesempatan untuk dapat melaksanakan kerjasama atau MOU dengan lembaga lain untuk meningkatkan sekolah dan Mendistribusikan instrumen untuk mendapatkan masukan, saran, dan ide kreatif dari masyarakat Menurut guru nonkomite tidak berhasil $(31,25 \%)$. Aspek yang belum berhasil yaitu dalam melaksanakan penyelidikan tentang kesempatan untuk dapat melaksanakan kerjasama atau MOU dengan lembaga lain demi kemajuan sekolah dan mendistribusikan instrumen untuk mendapatkan masukan, saran, dan ide kreatif dari masyarakat, dan memberikan laporan kepada sekolah secara tertulis, tentang hasil observasi terhadap sekolah.

\section{b. Mutu Sekolah SMA Negeri 02 (3 Tahun Terakhir 2018-2020)}

1) Dimensi Daya Tarik

Berdasarkan analisis data, dapat diketahui bahwa APK dan APM
SMAN 02 tiga tahun terakhir dari tahun 2018 sampai 2020 meningkat, yaitu 0,68 dan 0,81 dan menurut guru non komite sekolah sebesar $100 \%$ selalu mendapat bantuan pemerintah, adanya beasiswa bagi siswa berprestasi dan memberi kesempatan kepada guru untuk mengikuti pendidikan dan latihan (diklat), sedangkan menurut orangtua nonkomite sebesar $82,54 \%$.

2) Dimensi Relevansi

Berdasarkan analisis data, dapat diketahui bahwa tingkat relevansi keberadaan

sekolah dengan keadaan, sosial budaya masyarakat, keinginan dan yang dibutuhkan

oleh lingkungan masyarakat, dan lulusan sudah dapat melanjutkan ke tingkat sekolah diatasnya menurut kepala sekolah, komite sekolah sebesar $66,67 \%$, guru nonkomite $100 \%$, dan orangtua nonkomite $80,95 \%$.

3) Dimensi Efektifitas

Berdasarkan analisis data, dapat diketahui bahwa tingkat efektivitas sekolahdilihat dari prestasi guru tingkat daerah, nasional dan internasional, prestasi sekolahtingkat nasional dan intrenasional, prestasi siswa tingkat nasional dan internasional,jumlah anak melanjutkan sekolah, jumlah anak yang tidak melanjutkan, jumlah anakDO, nilai UN, Jumlah lulusan, jumlah anak yang tidak lulus dan jumlah anak yang mengulang kelas menurut kepala sekolah sebesar 50\%, dan guru nonkomite sebesar $90 \%$.

4) Dimensi Efisiensi 
Berdasarkan analisis data, dapat diketahui bahwa tingkat efisiensi sekolah dilihat dari dukungan prestasi yang diraih sekolah tanpa membuang waktu, tenaga dan biaya dan kemampuan SDM men-jalankan tugas dengan cermat, tepat, dan berdayaguna menurut kepala sekolah sebesar 50\%, dan guru nonkomite $87,55 \%$.

\section{c. Kinerja Komite Sekolah SMA Swasta Hang Tuah}

1) Dimensi Pemberi

Pertimbangan/AdvisoryAgency

Berdasarkan analisis data, dapat diketahui bahwa kinerja komite SMA swasta Hang Tuah dalam dimensi pemberi pertimbangan/adviseryageney menurut kepala sekolah sangat berhasil $(100 \%)$. Menurut guru nonkomite sudah berhasil 77,78\%). Aspek yang kurang berhasil yaitu menyusun masukan untuk penyusunan RAPBS, ikut mengesahkan RAPBS bersama kepala sekolah, memberikan pertimbangan tentang tenaga kependidikan yang dapat diperbantukan di sekolah. Menurut orangtua nonkomite sangat berhasil $(92,94 \%)$. Aspek yang belum berhasil yaitu memberikan pertimbangan tentang tenaga kependidikan yang dapat diperbantukan di sekolah dan ikut mengesahkan RAPBS bersama kepala sekolah.

2) Dimensi Pendukung Kegiatan Layanan
Pendidikan/Supporting Agency

Berdasarkan analisis data, dapat diketahui bahwa kinerja komite SMA swasta Hang Tuah dalam dimensi pendukung kegiatan layanan pendidikan/supporting agency menurut kepala sekolah sudah berhasil (75\%). Aspek yang belum berhasil yaitu dalam hal memantau angka mengulang sekolah, dan memantau angka bertahan sekolah. Menurut orangtua nonkomite sudah berhasil $(89,3 \%)$. Aspek yang dirasakan belum berhasil yaitu dalam hal mengontrol proses perencanaan pendidikan di sekolah dan melakukan pengawasan terhadap kualitas program sekolah. Menurut guru nonkomite kurang berhasil $(60,4 \%)$. Aspek yang kurang berhasil yaitu dalam hal pengawasan terhadap kualitas perencanaan sekolah, memantau penjadwalan program sekolah, memantau partisipasi stakeholder pendidikan dalam pelaksanaan program sekolah dan memantau angka bertahan sekolah.

3) Dimensi Pengontrol Kegiatan Layanan Pendidikan/Controlling Agency

Berdasarkan analisis data, dapat diketahui bahwa kinerja komite SMA swasta Hang Tuah dalam dimensi pengontrol kegiatan layanan pendidikan/controllingagency menurut kepala sekolah sudah berhasil (72,73\%). Aspek yang belum berhasil yaitudalam hal memantau angka partisipasi sekolah, memantau angka 
mengulang sekolah, dan memantau angka bertahan di sekolah. Menurut orangtua nonkomite sudah berhasil $(89,8 \%)$. Aspek yang belum berhasil lebih dalam hal mengawasi kualitas perencanaan sekolah, memantau angka bertahan di sekolah, dan mengawasi terhadap kualitas program sekolah. Menurut guru nonkomite kurang berhasil (57,6\%). Aspek yang belum berhasil yaitu dalam hal mengontrol proses pengambilan keputusan di sekolah, memantau partisipasi stakeholder pendidikan dalam pelaksanaan program sekolah.

4) Dimensi Penghubung/MediatorAgency Berdasarkan analisis data, dapat diketahui bahwa kinerja komite SMA swasta Hang Tuah desa dalam dimensi penghubung/mediatoragency menurut kepala sekolah kurang berhasil (50\%). Aspek yang belum berhasil yaitu dalam menyebarkan kuesioner untuk memperoleh masukan, saran, dan ide kreatif dari masyarakat dan menyampaikan laporan kepada sekolah secara tertulis, tentang hasil pengamatannya terhadap sekolah. Menurut guru nonkomite kurang berhasil $(54,2 \%)$. Aspek yang belum berhasil yaitu dalam aspek mengadakan penjajagan tentang kemungkinan untuk dapat mengadakan kerjasama atau MOU dengan lembaga lain untuk memajukan sekolah dan membina hubungan dan kerjasama yang harmonis dengan seluruh stakeholder pendidikan.

\section{d. Mutu Sekolah SMA swasta Hang Tuah Tiga Tahun Terakhir (2018-2020)}

1) Dimensi Daya Tarik

Berdasarkan analisis data, dapat diketahui bahwa APK dan APM SMA swasta Hang Tuah tiga tahun terakhir dari tahun 2018 sampai 2020 meningkat, yaitu 0,81 dan 0,82 dan menurut responden kepala sekolah $100 \%$, karena sekolah selalu mendapat bantuan pemerintah, adanya beasiswa bagi siswa berprestasi dan memberi kesempatan kepada guru untuk ikut pendidikan dan latihan (diklat), tetapi menurut guru non komite sebesar $56,67 \%$, serta orangtua nonkomite sebesar $84,70 \%$.

2) Dimensi Relevansi

Berdasarkan analisis data, dapat diketahui bahwa tingkat relevansi keberadaan sekolah dengan keadaan sosial budaya masyarakat, keinginan dan yang dibutuhkan oleh lingkungan masyarakat, dan lulusan sudah dapat melanjutkan ke tingkat sekolah di atasnya menurut kepala sekolah, dan guru nonkomite sebesar $100 \%$, dan orangtua nonkomite sebesar $96,86 \%$.

3) Dimensi Efektifitas

Berdasarkan analisis data, dapat diketahui bahwa tingkat efektivitas sekolah dilihat dari prestasi guru tingkat daerah, nasional dan intrenasional, prestasi tekolah tingkat nasional dan intrenasional, prestasi 
siswa tingkat nasional dan internasional, jumlah anak melanjutkan sekolah, jumlah anak yang tidak melanjutkan, jumlah anak DO, nilai UN, jumlah lulusan, jumlah anak yang tidak lulus, dan jumlah anak yang mengulang kelas menurut kepala sekolah, dan guru nonkomite sebesar $80 \%$.

4) Dimensi Efisiensi

Berdasarkan analisis data, dapat diketahui bahwa tingkat efisiensi sekolah dilihat dari dukungan prestasi yang diraih sekolah tanpa membuang waktu, tenaga dan biaya dan kemampuan SDM menjalankan tugas dengan cermat, tepat, dan berdaya guna menurut kepala sekolah sebesar $50 \%$, dan guru nonkomite $40,91 \%$.

\section{E. SIMPULAN}

Berdasarkan Uraian pembahasan di atas dapat disimpulkan adalah.

\section{a. Kinerja Komite Sekolah SMA Negeri 02}

1) Dimensi Pemberi

Pertimbangnn/advisoryagency

Kinerja komite sekolah SMA Negeri 02 menurut kepala sekolah masih kurang berhasil. Aspek yang belum berhasil yaitu dalam hal memberikan pertimbangan tentang tenaga kependidikan dan prasarana yang dapat diperbantukan di sekolah. Menurut guru nonkomite sudah berhasil.
Menurut orang tua non komlte sudah sangat berhasil.

2) Dimensi Pendukung Kegiatan Layanan Pendidikan/supporting agency

Kinerja komite sekolah SMA Negeri 02 menurut kepala sekolah sudah sangat berhasil. Menurut guru nonkomite sudah berhasil. Menurut orangtua nonkomite sudah sangat berhasil. Aspek yang belum berhasil antara lain dalam hal melakukan pengawasan terhadap kualitas perencanaan sekolah dan memantau angka bertahan sekolah.

3) Dimensi Pengontrol Kegiatan Layanan Pendidikan/controlling agency Kinerja komite sekolah SMA Negeri 02 menurut kepala sekolah sudah sangat berhasil. Menurut guru nonkomite juga sudah berhasil. Menurut orangtua nonkomite sangat berhasil. Aspek yang belum berhasil yaitu dalam hal mengontrol proses perencanaan pendidikan di sekolah dan memantau alokasi anggaran untuk pelaksanaan program sekolah.

4) Dimensi Penghubung/mediatoragency Kinerja komite sekolah SMA Negeri 02 menurut kepala sekolah kurang berhasil. Aspek yang belum berhasil yaitu dalam hal mengadakan penjajagan tentang kemungkinan untuk dapat mengadakan kerjasama atau MOU dengan lembaga lain untuk memajukan sekolah. Menurut guru nonkomite tidak berhasil yaitu menyebarkan kuesioner untuk 
memperoleh masukan, saran, dan ide

kreatif dari masyarakat dan menyampaikan laporan kepada sekolah secara tertulis, tentang hasil pengamatannya terhadap sekolah.

\section{b. Mutu Sekolah SMA Negeri 02, 3 Tahun Terakhir (2018-2020)}

1) Dimensi Daya Tarik

Tiga tahun terakhir jumlah rombongan belajar meningkat yaitu 0,68 dan 0,81 dan menurut guru nonkomite sekolah, selalu mendapat bantuan pemerintah, adanya beasiswa bagi siswa berprestasi dan memberi kesempatan kepada guru untuk mengikuti pendidikan dan latihan (diklat).

2) Dimensi Relavansi

Relevansi keberadaan sekolah dengan keadaan sosial budaya masyarakat, keinginan, dan kebutuhan masyarakat, sudah dapat dipenuhi, baik menurut kepala sekolah, orangtua nonkomite dan guru nonkomite.

3) Dimensi Efektifitas

Tingkat efektivitas sekolah dilihat dari prestasi siswa, jumlah anak melanjutkan tekolah, jumlah anak yang bekerja, jumlah lulusan sudah sesuai dengan harapan masyarakat, menurut kepala sekolah dan guru nonkomite.

4) Dimensi Efisiensi

Tingkat efisiensi sekolah dilihat dari dukungan prestasi yang diraih sekolah tanpa membuang waktu, tenaga, dan biaya serta menjalankan tugas dengan cermat, tepat, dan berdayaguna, sudah baik menurut kepala sekolah dan guru nonkomite.

\section{c. Kinerja Komite Sekolah SMA swasta Hang Tuah}

1) Dimensi Pemberi Pertimbangan/advisory agency

Kinerja komite sekolah SMA swasta Hang Tuah menurut kepala sekolah sangat berhasil. Menurut guru nonkomite sudah berhasil. Orangtua nonkomite sangat berhasil. Aspek yang belum berhasil yaitu menyampaikan pandangan tentang tenaga kcpendidikan yang dapat diperbantukan di sekolah dan andil menetapkan RAPBS bersama kepala sekolah.

2) Dimensi Pendukung Kegiatan Layanan Pendidikan/supporting agency

Kinerja komite sekolah SMA swasta Hang Tuah menurut kepala sekolah sudah berhasil. Menurut orangtua nonkomite sudah berhasil. Menurut guru nonkomite kurang berhasil. Aspek yang kurang berhasil yaitu dalam hal memonitor terhadap mutu perencanaan sekolah, mengawasi penjadwalan program sekolah, mengawasi keikutsertaanstakeholder pendidikan dalam implementasi program sekolah.

3) Dimensi Pengontrol Kegiatan Layanan Pendidikan/controlling agency

Kinerja komite sekolah SMA swasta Hang Tuah menurut kepala sekolah sudah berhasil. Menurut orangtua nonkomite sudah berhasil. Menurut 
guru nonkomite kurang berhasil. Aspek yang belum berhasil yaitu dalam hal mengawasi angka keikutsertaan sekolah, mengawasi angka mengulang sekolah, dan mengawasi angka bertahan di sekolah.

4) Dimensi Penghubung/mediatoragency Kinerja komite sekolah SMA swasta Hang Tuah menurut kepala sekolah kurang berhasil. Aspek yang belum berhasil yaitu dalam mendistribusikan instrumen untuk mendapatkan masukan, saran, dan ide kreatif dari masyarakat dan menyampaikan laporan kepada sekolah secara tertulis, tentang hasil observasi terhadap sekolah. Menurut guru nonkomite kurang berhasil. Aspek yang belum berhasil yaitu dalam aspek mengadakan penjajagan tentang beranggapan untuk dapat melaksanakan kerjasamaatau MOU dengan lembaga lain untuk peningkatan sekolah dan membina hubungan dan kerjasama yang harmonis dengan seluruh stakeholder pendidikan.

\section{d. Mutu Sekolah SMA swasta Hang Tuah Tiga Tahun Terakhir (2018-2020)}

1) Dimensi Daya Tarik Jumlah rombongan belajar tiga tahun terakhir dari tahun 2018 sampai 2020 meningkat, yaitu 0,81 dan 0,82 , sekolah selalu mendapat bantuan pemerintah, beasiswa berprestasi dan memberi kesempatan kepada guru untuk ikut pendidikan dan latihan (diklat).

2) Dimensi Relevansi

Tingkat relevansi keberadaan sekolah dengan keadaan sosial budaya masyarakat, harapan masyarakat dapat terpenuhi terbukti jumlah lulusan sudah dapat bekerja dan melanjutkan ke tingkat sekolah di atasnya menurut kepala sekolah, dan guru nonkomite.

3) Dimensi Efektifitas

Tingkat efektivitas sekolah dilihat dari prestasi siswa, jumlah anak melanjutkan sekolah, dan jumlah lulusan, menurut kepala sekolah dan guru nonkomite sudah berhasil, berarti kinerja komite sudah memenuhi harapan masyarakat.

4) Dimensi Efisiensi

Tingkat efisiensi sekolah dilihat dari dukungan prestasi yang diraih sekolah tanpa membuang waktu, tenaga, dan biaya serta kemampuan SDM, menjalankan tugas dengan cermat, tepat, dan berdaya guna menurut kepala sekolah dan guru nonkomite sudah berhasil, berarti kinerja komite sudah memenuhi harapan masyarakat. 


\section{DAFTAR PUSTAKA}

Depdiknas. (2013). Standar Nasional Pendidikan. Sinar Grafika.

Depdiknas. (2014). Panduan Umum Dewan Pendidikan dan Komite Sekolah: Sambutan Direktur Jenderal Pendidikan Dasar dan Menen. Ditjen Dikdasmen Depdiknas.

Depdiknas. 2013. Standar Nasional Pendidikan. Jakarta: Sinar Grafika.

Dermawan, Wibisono. 2011. Manajemen Kinerja. Jakarta: Erlangga.

Irawan, Ade. 2012. Kontroversi Komite Sekolah. Tempo, selasa 7 Desember 2004. Jakarta: Indonesia Corroption Watch.

Jerome S, Arcaro. 2012. Pendidikan Berbasis Mutu. Yogyakarta: Pustaka Pelajar.

Mangkunegara, Anwar. 2012. Evaluasi Kinerja SDM. Bandung: Refika Aditama.

Mulyasa. (2013). Mulyasa. 2013. Manajemen Berbasis Sekolah, Konsep Strategi dan Implementasi. Bandung; Remaja Rosdakarya. Remaja Rosdakarya.

Redaksi Sinar Grafika. (2003). Undang - Undang Sistem Pendidikan Nasional. Sinar Grafika.

Sukmadinata, N. S. (2013). Metode Penelitian Pendidikan. Remaja Rosdakarya.

Sukmadinata, N. S. (2014). Pengendalian Mutu Pendidikan Sekolah Menengah. Refika Aditama.

Suryadi, A. (2013). Sosialisasi Pemberdayaan Dewan Pendidikan dan Komite Sekolah. Mendiknas Bidang Desentralisasi Pendidikan.

Soenarjo, Soejoso. 2013. Komite Sekolah Perlu Proses Bertahap dan Komitmen Jangka Panjang, Kompas, 04 Agustus 200. Jakarta: Didaktika.

Syafudin. 2012. Manajemen Mutu Terpadu dalam Pendidikan. Jakarta: Grasindo.

Wibisono, D. (2011). Manajemen Kinerja. Erlangga. 